\title{
Are activity indices helpful in assessing active intestinal inflammation in Crohn's disease?
}

\author{
G CRAMA-BOHBOUTH, A S PEÑA, I BIEMOND, H W VERSPAGET, \\ D BLOK, J W ARNDT, I T WETERMAN, E $K$ J PAUWELS, AND \\ C B H W LAMERS
}

From the Department of Gastroenterology, and Diagnostic Radiology, Division of Nuclear Medicine, University Hospital, Leiden, The Netherlands

SUMMARY We have investigated the correlation of $24 \mathrm{~h}$ and $48 \mathrm{~h}$ faecal Indium-111 excretion with each other and with several clinical activity indices for Crohn's disease (CD): Crohn's disease activity index (CDAI), activity index (AI), simple index (SI), Oxford score, and laboratory parameters, such as ESR, serum albumin, orosomucoid, C-reactive protein, alpha-l-antitrypsin $\left(\alpha_{1}-\mathrm{AT}\right)$ faecal concentration, and $\alpha_{1}$-AT clearance in $58 \mathrm{CD}$ patients (37 with small bowel and 21 with colonic disease). A significant correlation was found between 24 and $48 \mathrm{~h}$ faecal Indium-111 excretion for small bowel $(r=0.708, p<0 \cdot 0001)$ and colonic disease $(r=0.994, p<0 \cdot 0001)$. The median faecal Indium-111 excretion for colonic involvement $(4 \% ; 0 \cdot 15-50 \%$ median and range) was significantly $(p<0.0005)$ higher than that for small bowel disease $(0 \cdot 45 \% ; 0 \cdot 03-2.9 \%)$. No significant correlation was found between faecal Indium-111 excretion and any activity index in the patients with small bowel disease, while in the group of patients with colonic localisation only the AI showed a significant correlation $(r=0.593, p<0.02)$. Faecal Indium-111 excretion was significantly correlated with $\alpha_{1}$-AT clearance $(r=0 \cdot 712, p<0 \cdot 0001)$ and faecal $\alpha_{1}$-AT concentration $(r=0.750, p<0.0001)$ in small bowel and in colonic localisation $(r=0.530, p<0 \cdot 02$ and $r=0 \cdot 444$, $\mathbf{p}<\mathbf{0 . 0 5}$ ). Serum albumin was significantly correlated only in the group of patients with colonic disease $(r=-0.593, p<0 \cdot 05)$. The present study shows poor agreement between activity indices, serum parameters of activity and faecal Indium-111 excretion. As a good correlation was found with the $\alpha_{1}$-clearance, which reflects losses into the gut, these results may suggest that faecal Indium excretion does not only reflect activity of inflammation, but may relate to the extent of intestinal ulceration.

Crohn's disease is a chronic relapsing disease in which the clinical presentation varies considerably. Difficulties arise in accurately assessing the disease activity which is important in the management of the patient and in analysing prospective trials. Laboratory variables such as erythrocyte sedimentation rate (ESR), serum albumin, $C$ reactive protein and orosomucoid concentrations have been used but are not always reliable because they lack specificity for Crohn's disease.

Address for correspondence: Dr A S Peña, Department of Gastrocnterology, University Hospital, 2333 AA Leiden. The Netherlands.

Accepted for publication 24 January 1989.
During the last decade a number of clinical indices have been developed to try to standardise disease

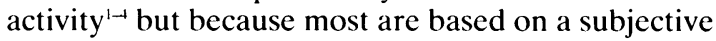
grading of signs and symptoms, none is considered as the final ideal index.

Measurement of clearance and faecal concentration of alpha-1-antitrypsin $\left(\alpha_{1}\right.$-AT) has been successfully used to estimate the degree of intestinal inflammation. ${ }^{5}$

More recently, the quantification of faecal excretion of intravenously administered autologous Indium-111 tropolonate labelled granulocytes has been introduced as a highly specific parameter for bowel inflammation, independent of the subjective 
complaints, and not influenced by the presence of possible coexisting diseases. ${ }^{(-11)}$

This prospective study was undertaken to investigate the correlation of the $24 \mathrm{~h}$ and $48 \mathrm{~h}$ faecal Indium-111 excretion and with several established activity indices, such as, the CDAI (Crohn's disease activity index), ${ }^{1}$ AI (activity index), ${ }^{2}$ SI (simple index), ${ }^{3}$ and Oxford scores, ${ }^{4}$ and with the following laboratory parameters, clearance and faecal concentration of $\alpha_{1}-\mathrm{AT}$, ESR, serum albumin, orosomucoid, and $\mathrm{C}$-reative protein.

\section{Methods}

PATIENTS

Fifty eight patients with Crohn's disease ( 34 women) with a median age of 35 years (range 16-60) were studied. The diagnosis was based on standard clinical, endoscopic and histopathologic features. Thirty seven patients had small bowel involvement only, and 21 colitis. In the group of 37 patients with small bowel disease, 21 had undergone surgery $(20$ an ileocoecal resection, three of whom also had a subtotal colectomy and one a proctocolectomy). Twelve patients were receiving corticosteroids.

Of the group of 21 patients with colonic involvement, 18 had extensive or total colitis, (of whom three had undergone a segmental colonic resection) and three patients had left sided colitis. Fifteen patients were receiving corticosteroids at the time of the study.

Forty eight hour faecal Indium-111 excretion was available in 25 patients with small bowel disease and in 12 patients with colonic involvement.

The Medical Ethics Committee of the University Hospital Leiden approved this investigation and informed consent was obtained from each patient.

\section{ACTIVITY INDICES}

The following activity indices for $\mathrm{CD}$ were used according to the published definitions given: Crohn's disease activity index (CDAI), activity index (AI), simple index (SI), ${ }^{3}$ Oxford score. ${ }^{+}$The following laboratory parameters were measured: ESR, serum albumin, orosomucoid, C-reactive protein, alpha-1antitrypsin $\left(\alpha_{1}-\mathrm{AT}\right)$ faecal concentration, and $\alpha_{1}$-AT clearance.

GRANULOCYTE LABELLING ANDEXCRETION OH INDIUM-111

Autologous granulocytes were separated and labelled with Indium-111 tropolonate, as previously described." An average of $200 \mu \mathrm{Ci}(7.4 \mathrm{MBq})$ was injected in each study. Indium-111 activity of stools was measured in a gammacounter and expressed as per cent of the injected dose after correction for decay.
Faecal Indium-111 excretion and $\alpha_{1}$-AT were measured in identical stool samples. Assessment of activity indices, stool, and blood collection were carried out on the same day.

DETERMINATION OF ALPHA- 1 -ANTITRYPSIN $\left(\alpha_{1}-\mathrm{A}\right.$ T $)$

Serum and $24 \mathrm{~h}$ stools were collected for $\alpha_{1}$-AT measurements. After weighing the total amount of wet faeces, two aliquots $(200-500 \mathrm{mg})$ were taken at random and lyophilised. The dried aliquots were weighed, suspended in saline and homogenised. After centrifugation the $\alpha_{1}$-AT concentration in the supernatant and in the serum were measured by radial immunodiffusion (for faeces, LC Partigen plate, Behring Werke AG, Marburg, FRG; for serum, Endoplates, Kallestad, Austin, Tx, USA). The $\alpha_{1}$-AT clearance was calculated as follows:

$$
\text { clearance }(\mathrm{ml} / 24 \mathrm{~h})=\frac{\mathrm{PC}_{\mathrm{f}}}{\mathrm{C}_{\mathrm{s}}}
$$

where $\mathrm{P}$ is the product of the wet weight of the $24 \mathrm{~h}$ faecal sample and the ratio dry weight/wet weight. $C_{f}$ is the concentration of $\alpha_{1}$-antitrypsin in lyophilised faeces ( $m g \alpha_{1}$-AT/g dry faeces) and $C_{\mathrm{s}}$ is the concentration in serum $\left(\mathrm{mg} \alpha_{1}-\mathrm{AT} / \mathrm{ml}\right)$.

SERUM LABORATORY PARAMETERS

Serum albumin was determinated by automated bromocresol green method and was expressed in $\mathrm{g} / \mathrm{l}$. Human $\alpha_{1}$-glycoprotein (orosomucoid) and C reactive protein were measured by radial immunodiffusion and expressed in $\mathrm{g} / \mathrm{l}$ and in $\mathrm{mg} / \mathrm{l}$, respectively.

STATISTICAL ANALYSIS

Results are expressed as median and range. They were analysed for statistical significance using the non parametrical two tailed Wilcoxon's rank-sum test.

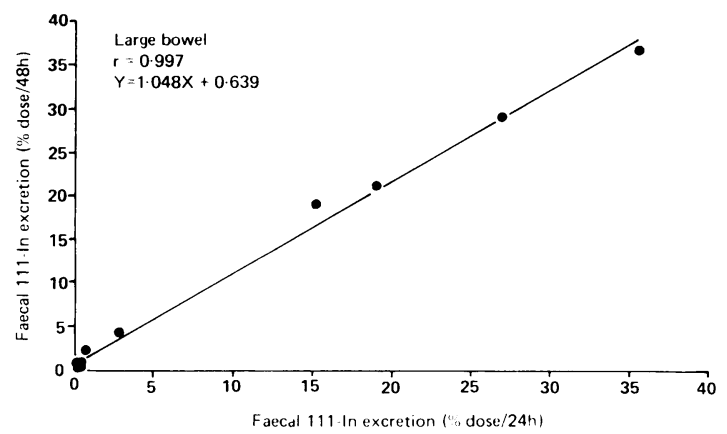

Fig. 1 Correlation between $24 \mathrm{~h}$ and $48 \mathrm{~h}$ faecal Indium- $11 \mathrm{I}$ excretion in patients with colonic involvement of Crohn's disease $(n=12)(r=0.994)(p<0.0001)$. 
Correlation was evaluated using the two tailed Pearson's correlation coefficient.

\section{Results}

As shown in Figures 1 and 2 a significant correlation was found between 24 and $48 \mathrm{~h}$ faecal excretion for colonic disease $(r=0.994)$ and for small bowel localisation $(r=0 \cdot 708)$. We therefore used $24 \mathrm{~h}$ faecal Indium111 excretion for the analysis of our results.

The median $24 \mathrm{~h}$ Indium-111 faecal excretion was significantly higher $(\mathrm{p}<0.0005)$ in patients with colonic involvement (median $4 \%$, range $0 \cdot 15-50 \%$ ) than in the group of patients with small bowel disease $(0.44 \%, 0.03-2.9 \%)$.

Table 1 shows the correlation between Indium-111 faecal excretion and the activity indices CDAI, AI, SI and Oxford score in the groups of patients with colonic and small bowel localisation separated and combined. As shown in this Table no significant correlation was found between Indium-111 excretion and any activity index for patients with small bowel disease. A significant correlation with the AI $(p<0.05)$, however, was found for colonic localisation and when the groups were analysed combined $(\mathrm{p}<0 \cdot 001)$.

Table 2 shows the correlation between faecal Indum-111 excretion and the various laboratory

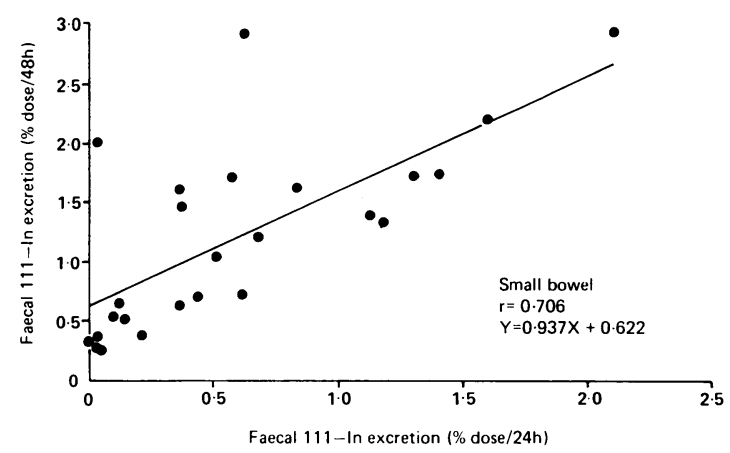

Fig. 2 Correlation between $24 \mathrm{~h}$ and $48 \mathrm{~h}$ faecal Indium-1/l excretion in patients with small bowel involvement of Crohn's disease $(n=25)(r=0 \cdot 708)(p<0 \cdot 0001)$.

parameters (ESR, C-reactive protein, serum albumin and orosomucoid), the $\alpha_{1}$-AT clearance, and $\alpha_{1}$-AT faecal concentration. A significant correlation was found with $\alpha_{1}$-AT clearance and faecal concentration in patients with either localisation $(\mathrm{p}<0.002)$ (Figs. 3,4).

The $\alpha_{1}$-AT clearance and $\alpha_{1}$-AT faecal concentration were higher in the group with colonic disease (median 193, range $100-426 \mathrm{ml} / 24 \mathrm{~h}$; median 8 , range $7 \cdot 0-26.0 \mathrm{mg}-\mathrm{g}$ ) than in the group with ileal involve-

Table 1 Coefficients ( $r$ ) and p-values of the correlation between Indium-111 faecal excretion and activity indices for Crohn's disease

\begin{tabular}{|c|c|c|c|c|c|c|}
\hline \multirow{3}{*}{ Localisation } & \multicolumn{6}{|c|}{ Faecal Indium-111 excretion } \\
\hline & \multicolumn{2}{|c|}{ Small bowel (37) } & \multicolumn{2}{|c|}{ Large bowel (21) } & \multicolumn{2}{|c|}{ Combined (58) } \\
\hline & $r$ & $p$ & $r$ & $p$ & $r$ & $p$ \\
\hline CDAI & $-0 \cdot 314$ & $0 \cdot 075$ & $-0 \cdot 042$ & $0 \cdot 870$ & $0 \cdot 160$ & $0 \cdot 267$ \\
\hline SI & $-0 \cdot 303$ & $0 \cdot 086$ & $0 \cdot 022$ & 0.931 & $0 \cdot 130$ & 0.365 \\
\hline Oxford scoret & 0.113 & 0.653 & $0 \cdot 108$ & 0.782 & 0.386 & 0.046 \\
\hline AI & 0.189 & 0.284 & 0.593 & $0.012 *$ & 0.524 & $<0 \cdot(0) 1^{*}$ \\
\hline
\end{tabular}

*statistically significant: $\uparrow$ calculated in 18 patients with small bowel and nine with large bowel CD.

Table 2 Coefficients ( $r$ ) and p-values of correlation between Indium-III faecal excretion and various laboratory parameters

\begin{tabular}{|c|c|c|c|c|c|c|}
\hline \multirow{3}{*}{ Localisution } & \multicolumn{6}{|c|}{ Faecal Indium-111 excretion } \\
\hline & \multicolumn{2}{|c|}{ Small howel (37) } & \multicolumn{2}{|c|}{ Large bowel (21) } & \multicolumn{2}{|c|}{ Combined (58) } \\
\hline & $r$ & $p$ & $r$ & $p$ & $r$ & $p$ \\
\hline ESR & $0 \cdot 060$ & 0.732 & 0.135 & 0.782 & 0.291 & $0.035 *$ \\
\hline \multicolumn{7}{|l|}{ C-reactive } \\
\hline Albumin & $0 \cdot 210$ & 0.226 & -0.593 & $0.012 *$ & -0.528 & $<0 \cdot\left(001^{*}\right.$ \\
\hline Orosomucoid $\dagger$ & 0.281 & $0 \cdot 132$ & $0 \cdot 322$ & $0 \cdot 178$ & 0.369 & $0.009 *$ \\
\hline$\alpha_{1}-$ AT clearance & 0.712 & $<0 \cdot\left(0001^{*}\right.$ & 0.530 & $0 \cdot 019^{*}$ & 0.413 & $0.0(0) 2 *$ \\
\hline$\alpha_{1}-\mathrm{AT}$ faecal concentration & $0 \cdot 750$ & $<0 \cdot 0001^{*}$ & 0.444 & $0.044^{*}$ & 0.425 & $0.002 *$ \\
\hline
\end{tabular}

*statistically significant: +measured in 30 patients with small bowel and 19 with large bowel localisation. 


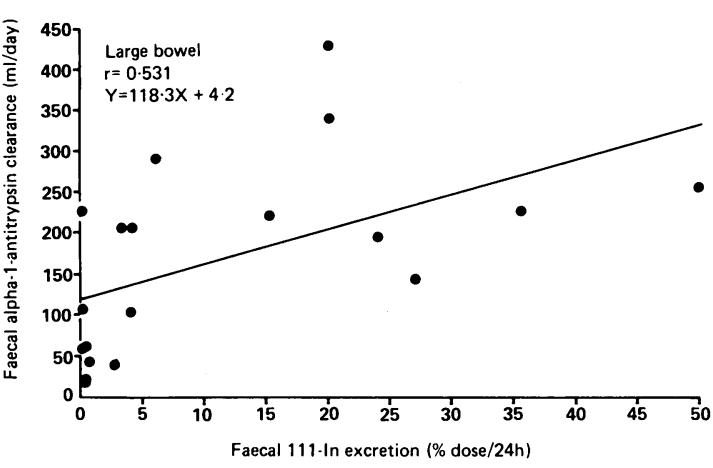

Fig. 3 Correlation between 24 h faecal Indium-111 excretion and $\alpha_{1}$-antitrypsin clearance in patients with colonic involvement of Crohn's disease $(n=21)(r=0 \cdot 530)$ $(p<0 \cdot 02)$.

ment (median 76 , range $7-365 \mathrm{ml} / 24 \mathrm{~h}$; median $4 \cdot 7$, range $0 \cdot 3-46 \cdot 7 \mathrm{mg}-\mathrm{g}$ ) but the difference did not reach statistical significance.

A significant negative correlation between faecal Indium-111 excretion and serum albumin was found only for patients with colonic involvement $(p<0.05)$ or when the groups were analysed combined. Furthermore serum orosomucoid correlated significantly with faecal Indium-111 excretion only when both localisations were taken together $(p<0 \cdot 05)$.

\section{Discussion}

In the present study $58 \mathrm{CD}$ patients, 37 with small bowel and 21 with colonic disease (CD) have been studied using several clinical indices of activity and laboratory parameters.

Because we have shown an excellent correlation between the $24 \mathrm{~h}$ and $48 \mathrm{~h}$ faecal Indium-111

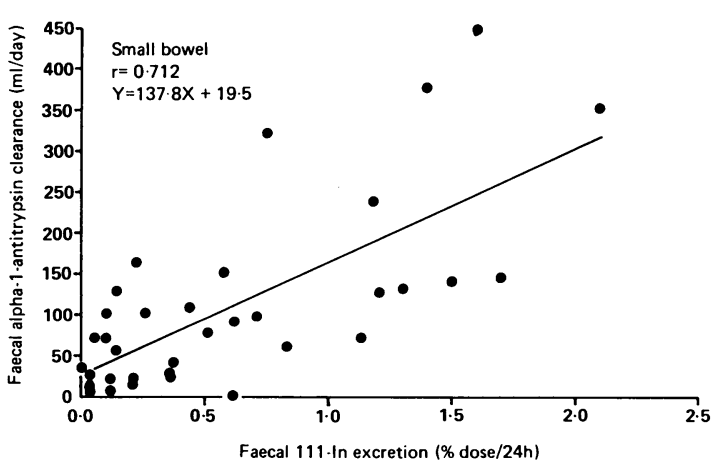

Fig. 4 Correlation between $24 \mathrm{~h}$ faecal Indium-111 excretion and $\alpha_{1}$-antitrypsin clearance in patients with small bowel involvement of Crohn's disease $(n=37)(r=0 \cdot 750)$ $(p<0.0001)$. excretion, the results of the $24 \mathrm{~h}$ faecal collection were used to compare the results obtained with other parameters. As far as we know previous studies using Indium-111 labelled granulocytes reported the results of faecal excretion of both localisations together. ${ }^{\circ 11} 12$ Saverymuttu et al ${ }^{\text {t }}$ showed a significantly higher four days faecal Indium-111 excretion in a group of $28 \mathrm{CD}$ patients with active inflammation than in 25 patients with the irritable bowel syndrome. Leddin et al ${ }^{12}$ studied a series of 16 patients with CD, 13 with UC, and 14 with other gastrointestinal diseases. All patients with active inflammation had a faecal Indium111 excretion higher than $0.70 \%$. In the present study, we found that faecal Indium-111 excretion in colonic disease was significantly higher than in small bowel disease. This may be the result of the different extent of inflammation in both localisations.

We have also found different correlations for the small and large bowel localisation. These results indicate that the disease behaves differently and therefore both groups should be analysed independently. This has been previously recorded in studies using Indium-111 granulocytes scintigraphy, where different results were found for colonic and small bowel disease."

A significant correlation was found between faecal Indium-111 excretion and $\alpha_{1}$-AT clearance in either localisation. Fischbach et al ${ }^{13}$, however, found no correlation between these two tests and the discrepancy may be because of differences in patient's selection, as they have mainly studied outpatients. Our results are in agreement with the findings of Meyers et al, 5 showing that the measurement of $\alpha_{1}$-AT concentration and clearance is a reliable method to assess active inflammation of the bowel.

Leddin et $a l^{12}$ and Fischbach et al ${ }^{13}$ found a significant correlation between the AI and the faecal Indium-111 excretion in their patients. We found that this is true only for colonic localisation, and in fact, their material was based on patients with predominantly colonic disease.

Saverymuttu et $a l^{14}$ found a significant correlation between Indium-111 excretion and the CDAI, which was not confirmed in this study. From all activity indices used in this study, the Al appears to be the best for reflecting gut inflammation in colonic disease. Another explanation for this discrepancy may be observer variation in calculating various indices for estimating the severity and activity of CD. De Dombal and Softley found that the AI had less interobserver variation than other indices.

It is not surprising that in colonic disease a significant correlation is also found for albumin as this biochemical parameter gives a special weight to the calculation of the AI.

Park et $a l^{14}$ have recently shown a very poor 
correlation in 19 patients with CD between activity demonstrated by Indium-111 oxine mixed leucocyte scintigraphy, clinical scores, and different laboratory parameters, including ESR, C-reactive protein, and ${ }^{i 1} \mathrm{CrCl}_{3}$ gastrointestinal protein loss test.

Fischbach et $a^{13}$ found a significant correlation between Indium-111 excretion and serum orosomucoid in $27 \mathrm{CD}$ patients. We also found a significant correlation in our patients but when the patients were analysed according to localisation no significant correlation was observed.

The faccal Indium-111 excretion showed a poor correlation with the activity indices or serum parameters of activity, such as ESR, CRP, and orosomucoid. A good correlation was found, however, with the $\alpha_{1}$-AT clearance, which reflects losses into the gut. These results may suggest that faecal Indium111 excretion does not only reflect activity of inflammation, but may be also related to the extent of intestinal ulceration.

Future prospective studies should be designed to assess the different contribution of degree of inflammation and extent of ulceration on the faecal excretion of Indium-111 and the clearance of $\alpha_{1}$-AT.

G E Crama-Bohbouth was supported by a grant of De Nederlandse Lever Darm Stichting. The authors would like to acknowledge the technical assistance of R I J Feitsma Ing, and Miss Loes Niepoth for typing the manuscript.

\section{References}

I Best WR, Becktel JM, Singleton JW. Kern F, Jr. Rederived values of eight coefficients of the CD activity index (CDAI). Gastroenterology 1979; 77: 843-6.

2 Van Hees PAM, van Elteren Ph, van Lier HJJ, van Tongeren JHM. An index of inflammatory activity in patients with Crohn's disease. Gut 1980; 21: 279-86.
3 Harvey RF. Bradshaw JM. A simple index of Crohn's Disease Activity. Lancet 198(); i: 514.

4 De Dombal FT. Softley A. IOIBD report no. 1: observer variation calculating indices of severity and activity in Crohn's discase. Gut 1987; 28: 474-81.

5 Meyers S, Wolke A. Field STP, Feuer EJ, Johnson JW. Janowitz HD. Fecal alpha-l-antitrypsin measurement: an indicator of Crohn's disease activity. Gastroenterology 1985: 89: 13-8.

6 Saverymuttu SH, Peters AM, Lavender JP, Pepys MB, Hodgson HJF. Chadwick VS. Quantitative faccal Indium 111-labeled leukocyte excretion in the assessment of disease in Crohn's discase. Gastroenterology 1983; 85: 1333-9.

7 Keshavarzian A, Price YE, Peters AM, Lavender JP. Wright NA. Hodgson HJF. Specificity of Indium-111 granulocyte scanning and fecal excretion measurement in inflammatory bowel discase - an autoradiographic study. Dig Dis Sci 1985: 30: 11.56-60.

8 Segal AW. Ensell J, Munro JA, Sarner M. Indium"'"tagged leuococytes in the diagnosis of inflammatory bowel discase. Lancet 1981: ii: 230-2.

9 Saverymuttu SH. Peters AM. Lavender JP. Hodgson HJF. Chadwick VS. Imaging diseased bowel with Indium"' labelled leucocytes. Br J Radiol 1981; 54: 707.

10 Saverymuttu SH, Camilleri M, Recs H. Lavender JP. Hodgson HJF, Chadwick VS. Indium 111-Granulocyte scanning in the assessment of disease extent and discase activity in inflammatory bowel discase. Gastroenterology 1986: 90: 1121-8.

11 Crama-Bohbouth GE, Arndt JW, Peña AS, et al. Value of Indium-111 granulocyte scintigraphy in the assessment of Crohn's disease of the small bowel. Digestion 1988; 40: 227-36.

12 Leddin D, Paterson W. DaCosta L. et al. Indium-111 labeled autologous leukocyte imaging and fecal excretion. Dig Dis Sci 1987; 32: 377-87.

13 Fischbach W. Becker W. Mössner J. Koch W, Reiners C. Faccal alpha-1-antitrypsin and excretion of "'Indium granulocytes in assessment of discase activity in chronic inflammatory bowel discases. (Fut 1987; 28: 386-93.

14 Park RHR. McKillop JH. Duncan A. MacKenzic JF. Russell RI. Can "indium autologous mixed leucocyte scanning accurately assess discase extent and activity in Crohn`s discase? Gut 1988; 29; 821-.5. 